\title{
ARTICLE OPEN \\ Recent changes in the South America low-level jet
}

\author{
Charles Jones (iD)
}

The South America Low-level Jet (SALLJ) is a climatological feature with a critical role in the spatiotemporal distribution of precipitation in South America. While previous studies have focused on the mechanisms and variability of the SALLJ in the central Andes (i.e., southeast Peru, Bolivia, and Paraguay), the occurrence of the low-level jet in the eastern slopes of the northern Andes (i.e., northeast Peru, Colombia, and Venezuela) and its linkages to the central region have not been previously explored. This study shows that the SALL in the northern branch exceeds $10 \mathrm{~m} \mathrm{~s}^{-1}$ during September-February and the frequency can be as high as in the central region. Moreover, the SALLJ can occur simultaneously or separately in both regions. When the SALLJ is active only in the northern branch, wind speeds are very low from Bolivia towards southeast South America (SESA) and precipitation is significantly reduced (1-4 $\mathrm{mm} \mathrm{day}^{-1}$ ) from climatology. In contrast, precipitation increases over eastern Bolivia by $2-4 \mathrm{~mm}$ day ${ }^{-1}$. Composites suggest that the SALL northern branch is forced by a large-scale circulation pattern with the enhancement of the North Atlantic Subtropical High driving northeasterly winds over the northern Andes. Further analysis shows that the frequency and intensity of the SALL in the northern Andes has substantially increased in the last 39 years.

npj Climate and Atmospheric Science (2019)2:20 ; https://doi.org/10.1038/s41612-019-0077-5

\section{INTRODUCTION}

The South America low-level jet (SALL) was first recognized in the 1980s with the aid of sparse radiosonde station data and satellitederived cloud winds. ${ }^{1-7}$ The South America low-level jet experiment $(S A L L E X)^{8}$ and the advent of reanalysis datasets have significantly contributed to the understanding of the SALL and its influence in the South American climate. ${ }^{7,9-14}$ The SALU reaches very high wind speeds in the eastern central Andes around Bolivia and is present year round., ${ }^{415-17}$ The SALL exhibits significant intraseasonal, interannual, and multidecadal variations. ${ }^{4,7,8,13,15}$ Furthermore, the low-level jet transports large amounts of moisture from the Amazon Basin towards the subtropics of South America ${ }^{12,18,19}$ and intense mesoscale convective systems (MCS), and heavy precipitation frequently develop near its exit region. ${ }^{20-23}$

Perhaps because the SALLJ reaches maximum wind speeds in the central Andes and is clearly identified in vertical wind profiles in Santa Cruz de La Sierra, Bolivia, and Mariscal Estigarribia, Paraguay, previous studies of the SALLJ have focused primarily on the mechanisms and variability of the jet in the central Andes. $^{4,7,8,12,16,24}$ Much less attention has been given to SALLJ incidences in the northern Andes defined here as the region including Venezuela, Colombia, and northeast Peru. The existence of a low-level jet over the Llanos region near Colombia and Venezuela was first recognized by Torrealba and Amador. ${ }^{25}$ This study shows that the seasonal frequency of the SALLJ in the northern Andes can be nearly as high as in the central Andes, and SALLJ occurrences in the northern Andes may occur simultaneously or independently from low-level jets in the central region (see Supplementary Fig. S1 for an example). Furthermore, when the SALLJ occurs over the northern Andes but not in the central region, the moisture supply by the jet significantly alters the spatial pattern of precipitation in South America with a considerable impact in the La Plata River drainage basin. Additionally, this study shows that SALLJ occurrences in the northern Andes have exhibited remarkable increasing trends in the last 39 years. We suggest that changes in the SALLJ in the northern Andes are linked to remotely forced suppressed convection and cooling in the tropical eastern Pacific in the last several decades.

\section{RESULTS}

In the following analysis, the variability of the SALLJ is analyzed with respect to its occurrences in the northern and central Andes. The central Andes is defined here by the region including locations in southern Peru (CE1: 12.42S, 70.133W, $294 \mathrm{~m}$ ), Bolivia (CE2: 17.81S, 63.16W, $400 \mathrm{~m}$ ), and Paraguay (CE3: 22.04S, 60.62W, $43 \mathrm{~m})$. Likewise, the northern Andes is defined by northern Peru (NO3: 3.63S, 75.62W, $173 \mathrm{~m}$ ), Colombia (NO2: 2.93N, 72.37W, $199 \mathrm{~m}$ ), and Venezuela (NO1: 8.18N, 67.45W, $54 \mathrm{~m}$ ) (indicated by open circles in Fig. S1 and the following figures). These regions were selected to geographically separate the northern and central Andes and, more importantly, based on trends in wind shear (see the section "Methods" and Fig. S6). The identification of the SALLJ shows that the low-level jet can occur only in the northern, only in the central, and simultaneously in both regions of the Andes. These variations of the SALLJ are defined as northern branch, central branch, and simultaneous SALLJ events. Because locations $\mathrm{NO} 1$ and NO3 are in the northern hemisphere, seasonal variations are referred by 3 months calendar (DJF, December, February, March; MAM, March, April, May; JJA, June, July, August; and SON, September, October, November).

Figure 1 shows seasonal vertical profiles of wind speeds during SALLJ days. As discussed in previous studies, SALLJ wind speeds exceed $10 \mathrm{~m} \mathrm{~s}^{-1}$ in all three locations in the central Andes (Fig. 1, right column), especially over Bolivia (CE2) and Paraguay (CE3); the low-level jet is maximum at $850 \mathrm{hPa}$. The jet is maximum in MAM and JJA in Bolivia (CE2) and Paraguay (CE3) and, interestingly, maximum in SON and DJF in southern Peru (CE1). A jet vertical

${ }^{1}$ Department of Geography, University of California, Santa Barbara, CA, USA
Correspondence: Charles Jones (cjones@eri.ucsb.edu)

Received: 13 February 2019 Accepted: 31 May 2019

Published online: 25 June 2019 
(a)

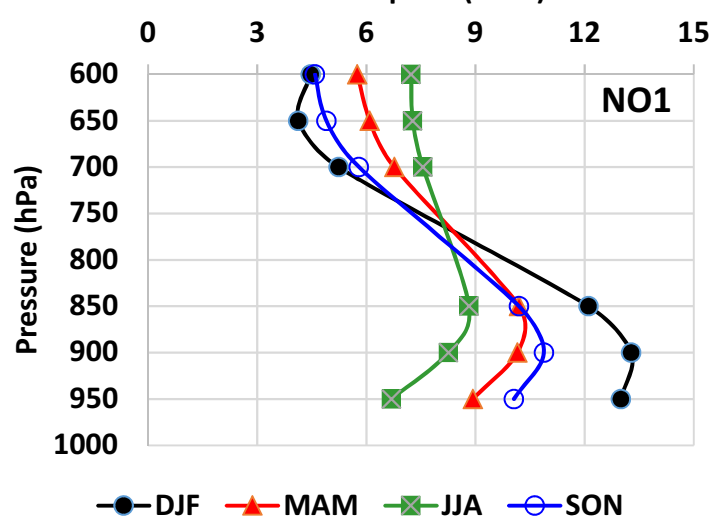

(b)

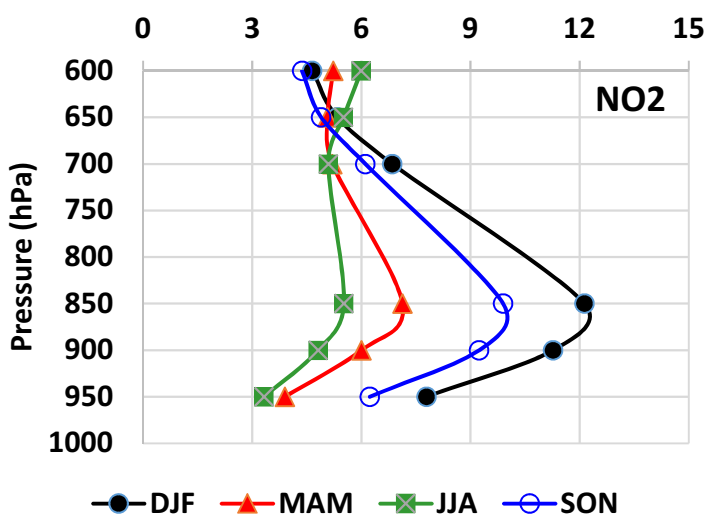

(c)

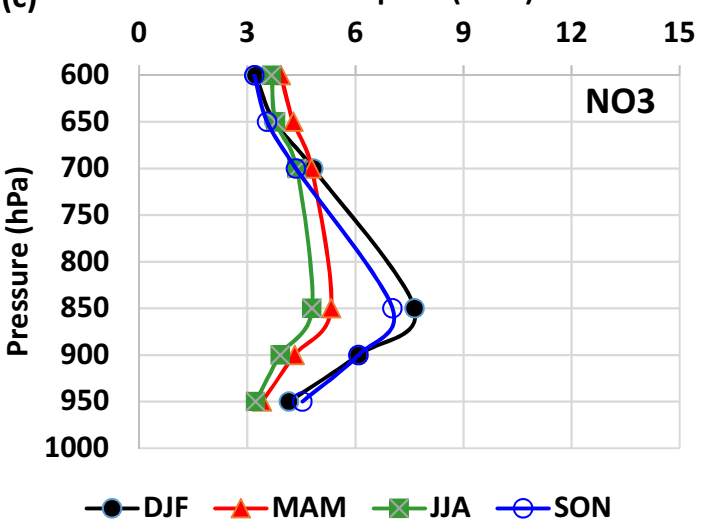

(d)

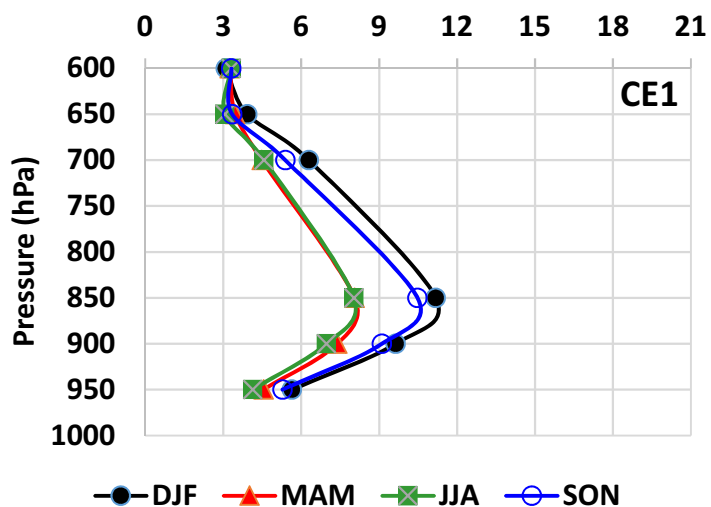

(e)

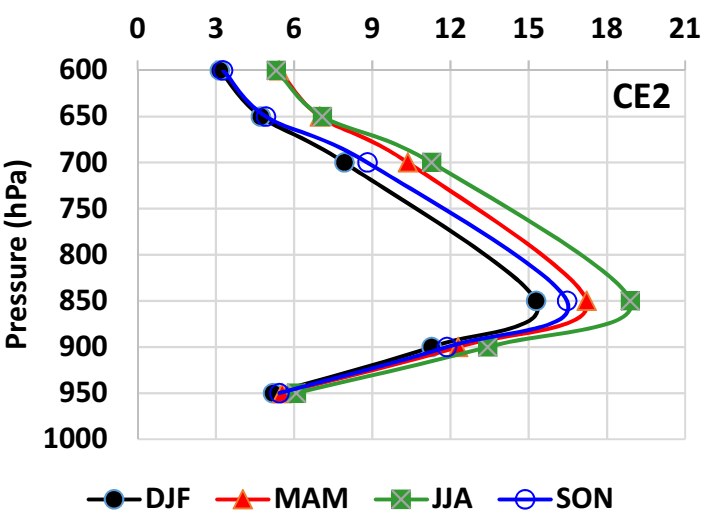

(f)

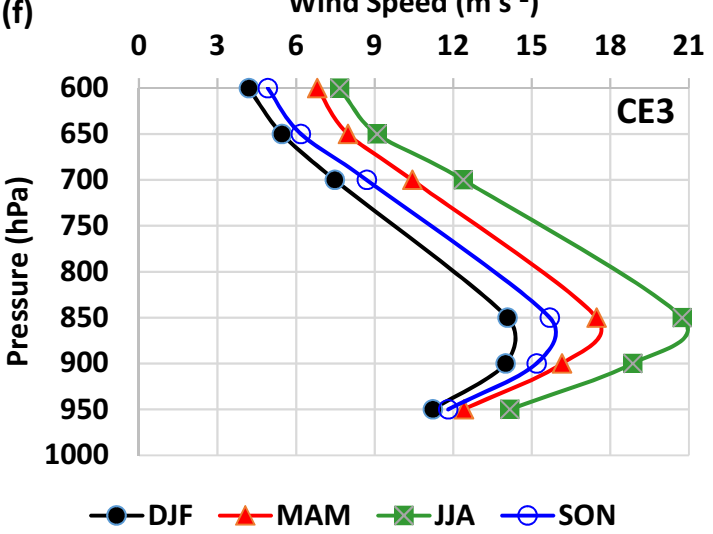

Fig. 1 Vertical wind profiles during SALLJ occurrences over the northern (left column) and central (right) Andes. Locations NO1, NO2, NO3, CE1, CE2, and CE3 are indicated by open circles in Fig. 2 (from north to south). Profiles are separated by each season

structure is also observed over the northern Andes (Fig. 1 left column); wind speeds over Venezuela (NO1) and Colombia (NO2) exceed $10 \mathrm{~m} \mathrm{~s}^{-1}$ during DJF and SON, while the low-level jet is considerably weaker in MAM and JJA. Except over Venezuela (NO1) where the jet is maximum at $900 \mathrm{hPa}$, the SALLJ is also maximum at $850 \mathrm{hPa}$ over Colombia (CE2) and northern Peru (CE3).

During SALLJ central branch events (Supplementary Fig. S2), the seasonal climatology of winds $(850 \mathrm{hPa})$ shows the typical pattern of trade winds from the equatorial Atlantic flowing over South America and systematically deflected by the Andes. Winds on the eastern slopes in the northern Andes near Venezuela and Colombia are on the order of $4-8 \mathrm{~m} \mathrm{~s}^{-1}$. In contrast, as expected, wind speeds higher than $10 \mathrm{~m} \mathrm{~s}^{-1}$ are observed around the central Andes. While wind speeds in the central Andes are generally largest during $\mathrm{JJA}$, moisture transport is indeed largest during SON and DJF 7,12 (not shown). During SALL central branch days (Supplementary Fig. S3), precipitation anomalies southward of the jet exit region over southeast South America (SESA) exceed $4 \mathrm{~mm}$ day $^{-1}$ in all seasons except during JJA.

Distinct climatological wind $(850 \mathrm{hPa})$ features are found during the SALLJ northern branch (Fig. 2). During DJF (Fig. 2a), easterly winds exceeding $8 \mathrm{~m} \mathrm{~s}^{-1}$ are observed over a large area in the western tropical Atlantic between $[5 \mathrm{~N}-17.5 \mathrm{~N} ; 100 \mathrm{~W}-40 \mathrm{~W}]$; this is the region where the Caribbean low-level jet (CLL) is active. ${ }^{26,27}$ At the core of the trade winds extending over the Caribbean, Central 


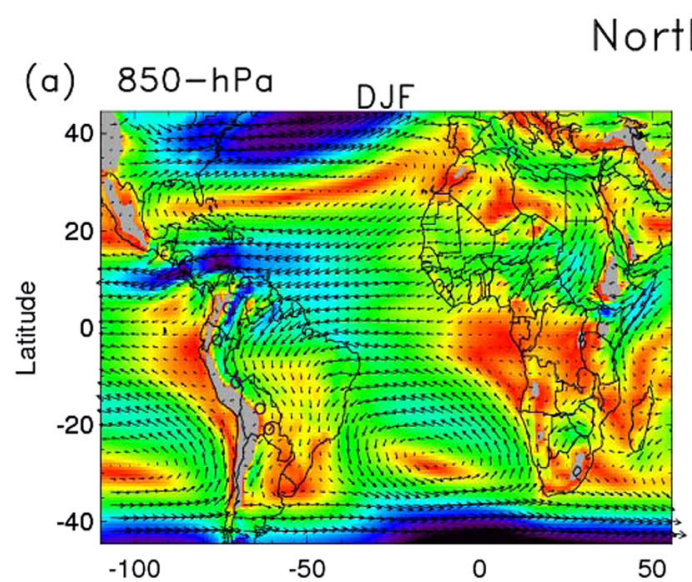

(c)

50

JJA

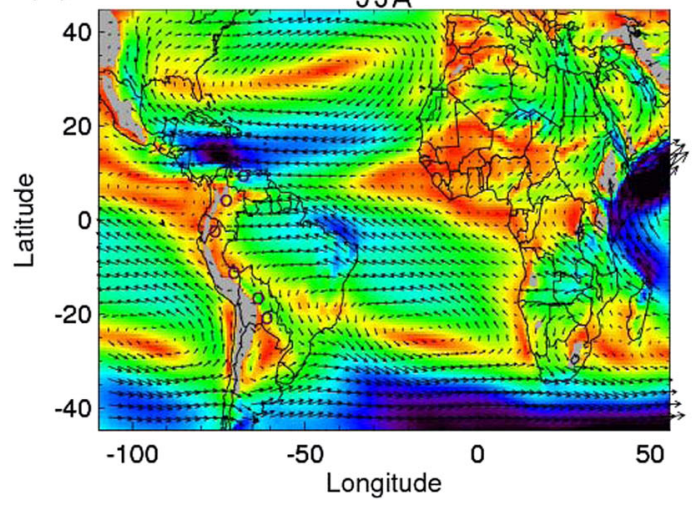

(d)

$$
\text { (b) SALLJ }
$$

(b)
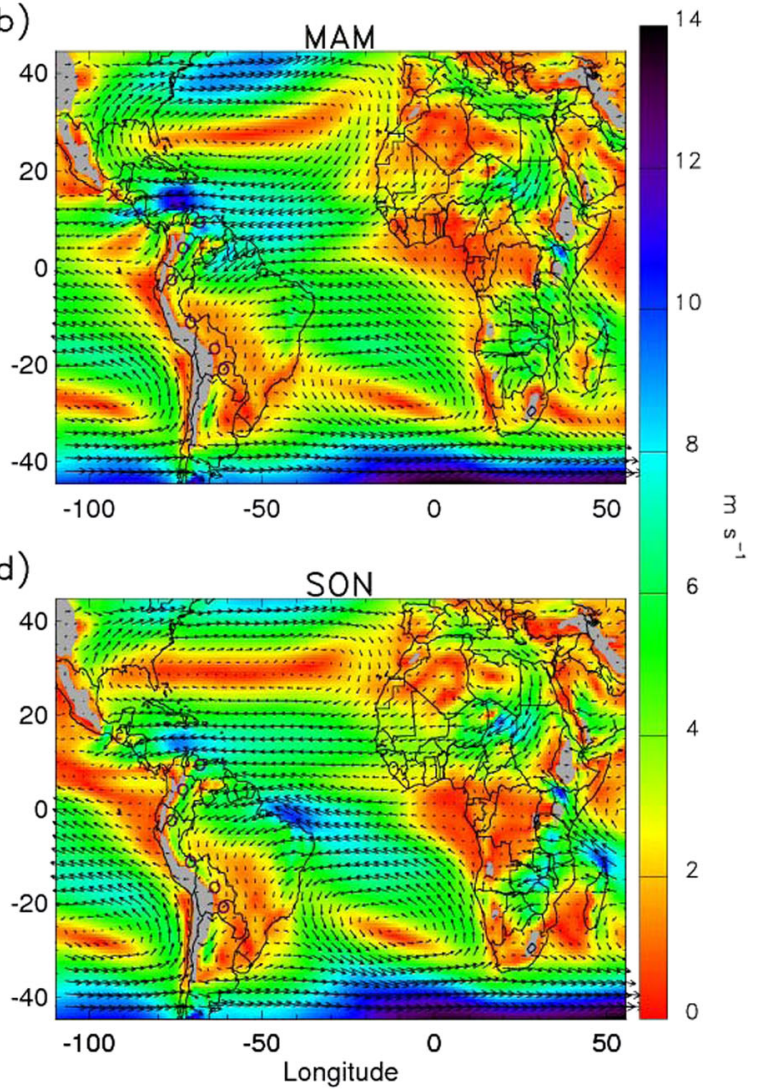

Fig. 2 Seasonal climatology of winds $(850 \mathrm{hPa})$ during SALLJ northern branch occurrences. a December-February, b March-May, c June-August, and d September-November, 1979-2017. Colors indicate wind speed. Open circles along the eastern Andes indicate reference locations used to identify SALLJ events in the northern and central regions. Gray shading indicates elevations $>1500 \mathrm{~m}$

America, and eastern Pacific, wind speeds exceed $10 \mathrm{~m} \mathrm{~s}^{-1}$. The trade winds in the Caribbean split into another branch which, influenced by the presence of the continent and the mountain barrier, flows southwestward to Venezuela, Colombia, and northern Peru reaching speeds higher than $10 \mathrm{~m} \mathrm{~s}^{-1}$ over a narrow extent known as Llanos. ${ }^{26}$ This jet is referred here as the northern branch of the SALLJ. During other seasons, when the SALLJ northern branch is active, the extent and intensity of the CLL is more pronounced than during SALLJ occurrences limited to the central Andes. Interestingly, when the SALLJ northern branch is active, wind speeds are very low from Bolivia towards SESA during all seasons (compare Fig. 2 and Supplementary Fig. S2).

The seasonal distributions of northern, central, and simultaneous SALLJ events are shown in Fig. 3. The frequency of SALL central branch shows weak seasonal variations with minimum in March-April and September. In contrast, the northern branch shows high frequency during October-April and minimum during JJA. Simultaneous SALLJ events show a similar seasonal pattern to the northern branch. These climatological differences in the northern, central, and simultaneous SALLJ have not been discussed in previous studies, and suggest that different mechanisms may control the activity of the low-level jet. It is interesting to note that there are more simultaneous SALLJ than separated lowlevel jets (northern/central branches) only in November-February. This is likely related to the fact that the SALLJ northern branch is strongest in DJF and is perhaps a limiting factor for the occurrence of simultaneous SALLJ throughout the year.

The influence of the northern branch SALLJ on precipitation is seen in Fig. 4, which shows precipitation anomalies for each season. When the northern branch is active, precipitation over

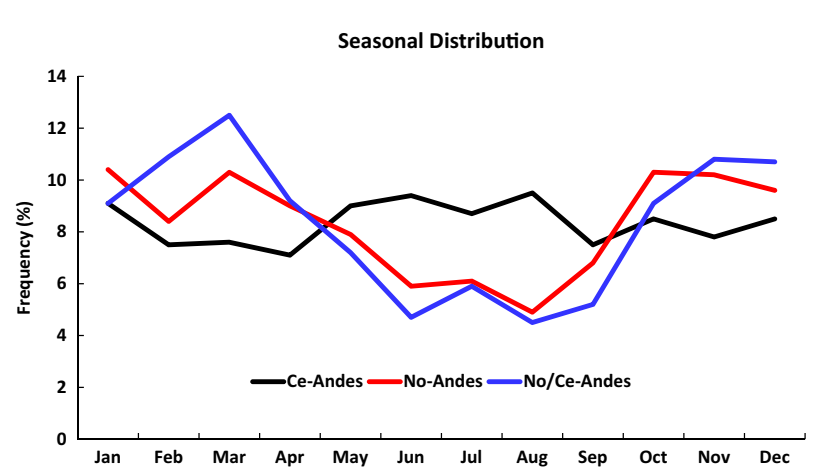

Fig. 3 Seasonal frequency distribution of low-level jet occurrences in the northern branch (red), central branch (black), and simultaneous occurrences (blue)

SESA decreases by $1-4 \mathrm{~mm}$ day $^{-1}$ during all seasons except in JJA, when anomalies are much weaker. In contrast, precipitation increases by $2-4 \mathrm{~mm}$ day $^{-1}$ on the eastern slopes of the central Andes near southeast Peru and northern Bolivia during DJF, MAM, and SON. These results provide additional support that the SALLJ northern branch is important even during MAM, when wind speeds are relatively weak (Fig. 1).

Differences in the large-scale atmospheric circulation patterns associated with northern and central low-level jet types are remarkable. Figure 5 shows the difference between SALLJ northern branch days and days with no low-level jet occurrences 

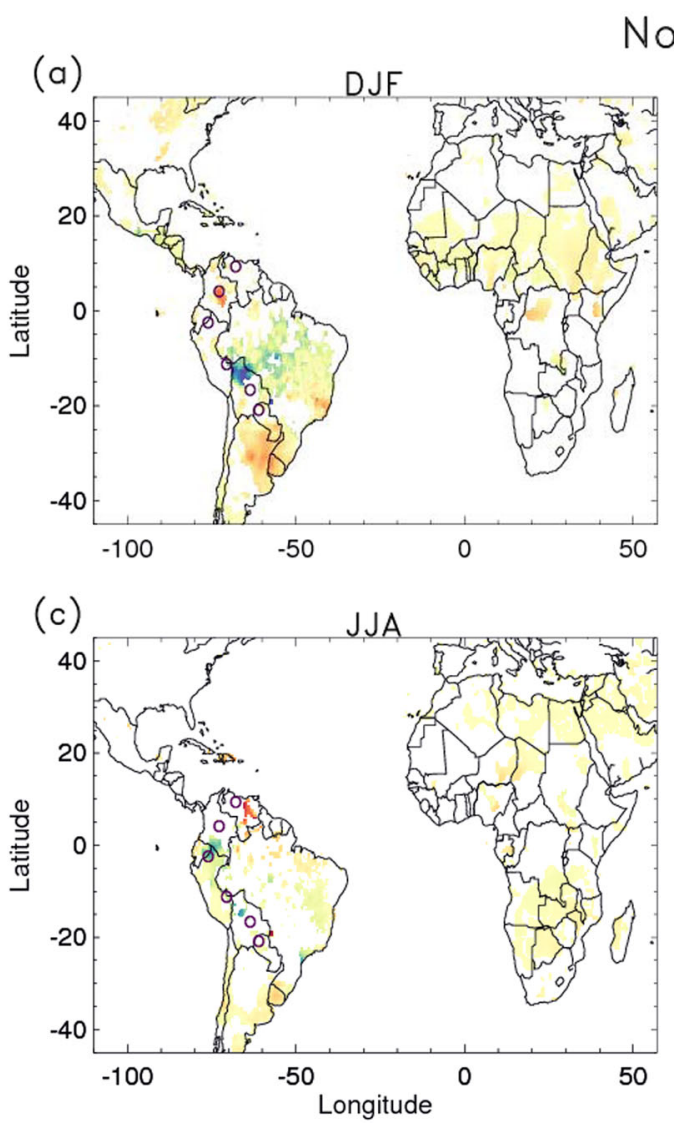

Northern SALLJ

(b)

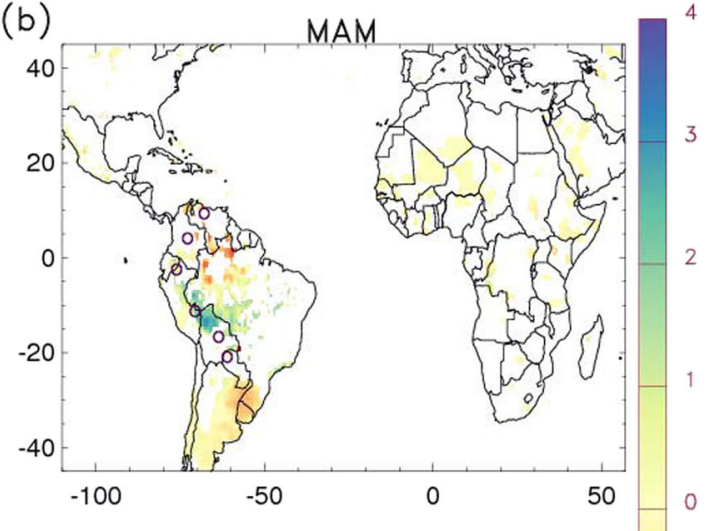

(d)

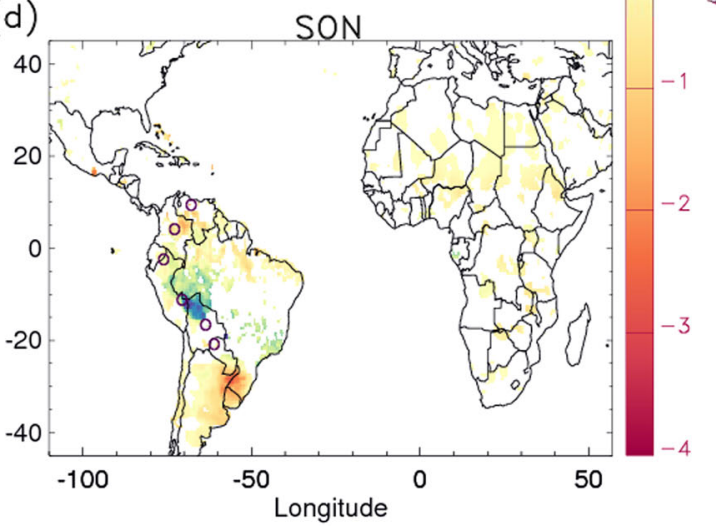

Fig. 4 Daily precipitation anomalies $\left(\mathrm{mm} \mathrm{yr}^{-1}\right)$ during SALLJ northern branch events: a December-February, b March-May, c June-August, and d September-November, 1979-2017. Colors indicate statistically significant (5\% level) differences in precipitation anomalies. Open circles indicate reference locations used to identify the SALLJ

in the northern region. Figure 5a shows differences in OLR, winds $(200 \mathrm{hPa})$ and SST anomalies; likewise, Fig. $5 \mathrm{~b}$ shows differences in wind anomalies at $850 \mathrm{hPa}$. A broad region with positive OLR anomalies extends from the west coast of South America towards the western Pacific coinciding with a cold tongue of negative SST anomalies (although not statistically significant). The largest OLR anomalies $\left(+3-5 \mathrm{~W} \mathrm{~m}^{-2}\right)$ are located over the dateline. A wavetrain pattern emanating from the tropical eastern Pacific to the extratropics of both hemispheres is observed in the wind circulation anomalies at 200 and $850 \mathrm{hPa}$. The enhancement of the North Atlantic Subtropical High-pressure (NASH) (Fig. 5b) is associated with northeasterly wind anomalies over the northern parts of South America and, therefore, contribute to the formation of the SALLJ northern branch. Interestingly, positive OLR anomalies exceeding $+7 \mathrm{~W} \mathrm{~m}^{-2}$ are observed over Colombia and Venezuela indicating suppressed convective activity. In contrast, the cyclonic circulation ( $850 \mathrm{hPa}$ ) anomaly (Fig. 5b) over South America and South Atlantic shows southeasterly wind anomalies inhibiting the formation of the SALL central branch. The circulation anomalies at $850 \mathrm{hPa}$ is associated with large negative OLR anomalies over South America, South Atlantic Convergence Zone (SACZ), and tropical Atlantic and indicative of enhanced precipitation. Furthermore, positive OLR anomalies over SESA indicate decreased precipitation.

An additional set of composites were constructed by taking the difference between northern and central branches SALLJ days (Supplementary Fig. S4). While the patterns in OLR, SST and wind $(200,850 \mathrm{hPa})$ anomalies are similar to Fig. 5, the magnitudes of the differences are larger especially in SST anomalies in the tropical Pacific Ocean. While the patterns of OLR and SST anomalies in Fig. 5 and Supplementary Fig. S4 suggest influences of cold El Niño/Southern Oscillation (ENSO) and Pacific Decadal Oscillation (PDO) phases, the occurrence of SALLJ northern branch events does not correspond to a particular phasing of ENSO and PDO (Supplementary Fig. S5).

In addition to the important role in the climate of South America, the SALLJ northern branch shows considerable positive long-term trends in the last 39 years. Figure 6 displays the monthly frequency (left column) and intensity (right column) of northern branch events (see the section "Methods"). Statistically significant positive trends are observed in frequency and intensity of the low-level jet in all three location in the northern Andes, although the rates of increase are larger over Venezuela (NO1) and Colombia (NO2) than in northern Peru (NO3). These trends in the frequency and intensity at NO1-3 can be placed in a broader context by investigating the $850-700 \mathrm{hPa}$ wind shear field. Supplementary Fig. S6 shows the Sen's slope estimator of trends in monthly wind shear anomalies $(850-700 \mathrm{hPa})$ during SALLJ northern branch events for each season separately. In all seasons, a large region of positive trends extends from the eastern tropical Atlantic towards the northern parts of South America and eastern Pacific. The increase in wind shear is especially large over northern Amazon and the SALLJ northern branch. In contrast, negative trends are observed over the central Andes indicating decreasing wind shear and, therefore, less favorable conditions for SALLJ occurrences in that region. This is consistent with Montini et al., ${ }^{7}$ who found negative trends in the frequency of SALLJ days in Santa Cruz de La Sierra and Mariscal Estigarribia during MAM. Interestingly, the largest negative trends in wind shear anomalies are found over southeast Brazil when the SALLJ is active in the northern Andes. 


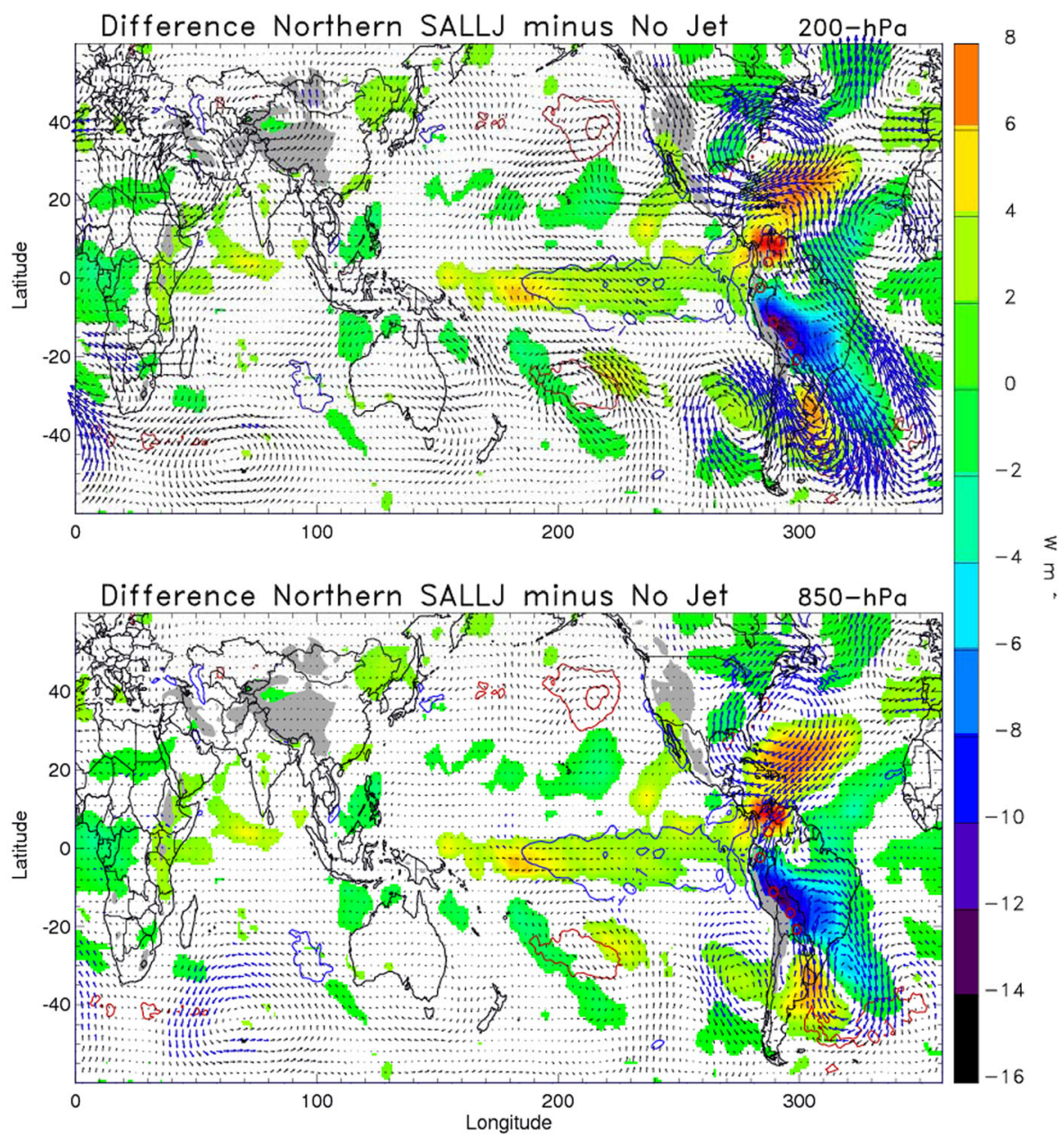

Fig. 5 Composite differences between samples with and without SALLJ northern branch events (i.e., low-level jet sample minus low-level jet free sample). Top: Colors indicate OLR anomalies and contours show SST anomalies; vectors indicate anomalies in winds at $200 \mathrm{hPa}$. Bottom: as on top panel, but for wind anomalies at $850 \mathrm{hPa}$. Colored regions and vectors indicate anomalies in OLR and winds (in blue) that are statistically significant at 5\% level. SST anomalies are not statistically significant, but are plotted for comparison with OLR anomalies. Gray shading indicates elevations $>1500 \mathrm{~m}$. Differences are computed for the entire 1 January 1979-31 December 2017 period for wind and SST anomalies and 1 January 1979-31 December 2016 for OLR

\section{DISCUSSION}

The SALLJ is a climatological feature with a critical role in the spatiotemporal distribution of precipitation in South America. The large majority of previous studies have focused on the mechanisms and variability of the SALLJ in the central Andes. Mechanisms proposed to explain the SALLJ include ${ }^{5,8,24}$ : (1) deflection of the easterly winds by the Andes as they flow over the Amazon basin and veer to north-northwest around the Andes "elbow", (2) local processes driven by sloping terrain and boundary layer diurnal cycle, and (3) pressure gradient perturbations associated with cross Andes flow. The cross Andes flow mechanism, in particular, proposes that the low-level jet in the central Andes is forced by zonal pressure gradients caused by an upstream trough and westerly winds crossing the mountains. While such mechanism is supported by observations ${ }^{16}$ and dry model experiments, ${ }^{17}$ the mechanism does not explain the nocturnal maximum of the jet.

This study investigated the nocturnal low-level jet that forms on the eastern slopes of the northern Andes in Venezuela, Colombia, and northeast Peru. The results show that the frequency of the low-level jet in the northern Andes can be as high as in the central Andes, and the low-level jet may occur simultaneously or separately in both regions. For this reason, the eastern Andes low-level jet needs to be analyzed accordingly as separate northern, central, and simultaneous SALLJ events. Wind speeds
$(850 \mathrm{hPa})$ of the SALLJ northern branch can exceed $10 \mathrm{~m} \mathrm{~s}^{-1}$ and are most intense in DJF and SON. The northern branch jet is also strongest at $850 \mathrm{~Pa}$ and a little shallower $(900 \mathrm{hPa})$ in the northernmost parts of the Andes. When the SALLJ is active in the northern branch, precipitation is enhanced in Bolivia on the eastern slopes of the central Andes, suggesting an enhancement of orographic precipitation. This suggests that moisture transport is cutoff further south and precipitation is suppressed over the SESA domain. Additional investigation does not reveal a systematic relationship between SALLJ northern branch and the phasing of ENSO and PDO.

The results presented here indicate that the mechanism of the SALL northern branch is quite different than the cross Andes flow mechanism proposed to explain the low-level jet in the central Andes. The SALLJ northern branch is forced by a large-scale circulation pattern in which the enhancement of the NASH and northeasterly winds over the northern Andes is forced by suppressed convective activity and cold SST anomalies in the tropical eastern Pacific (Fig. 5 and Supplementary Fig. S4). Although it is not the scope of this study, this raises the question: what mechanism (or mechanisms) is associated with simultaneous occurrences of the SALLJ northern and central branches.

Montini et al. ${ }^{7}$ developed a new climatology of the SALLJ with a focus in the central branch. They showed that the SALLJ reveals 

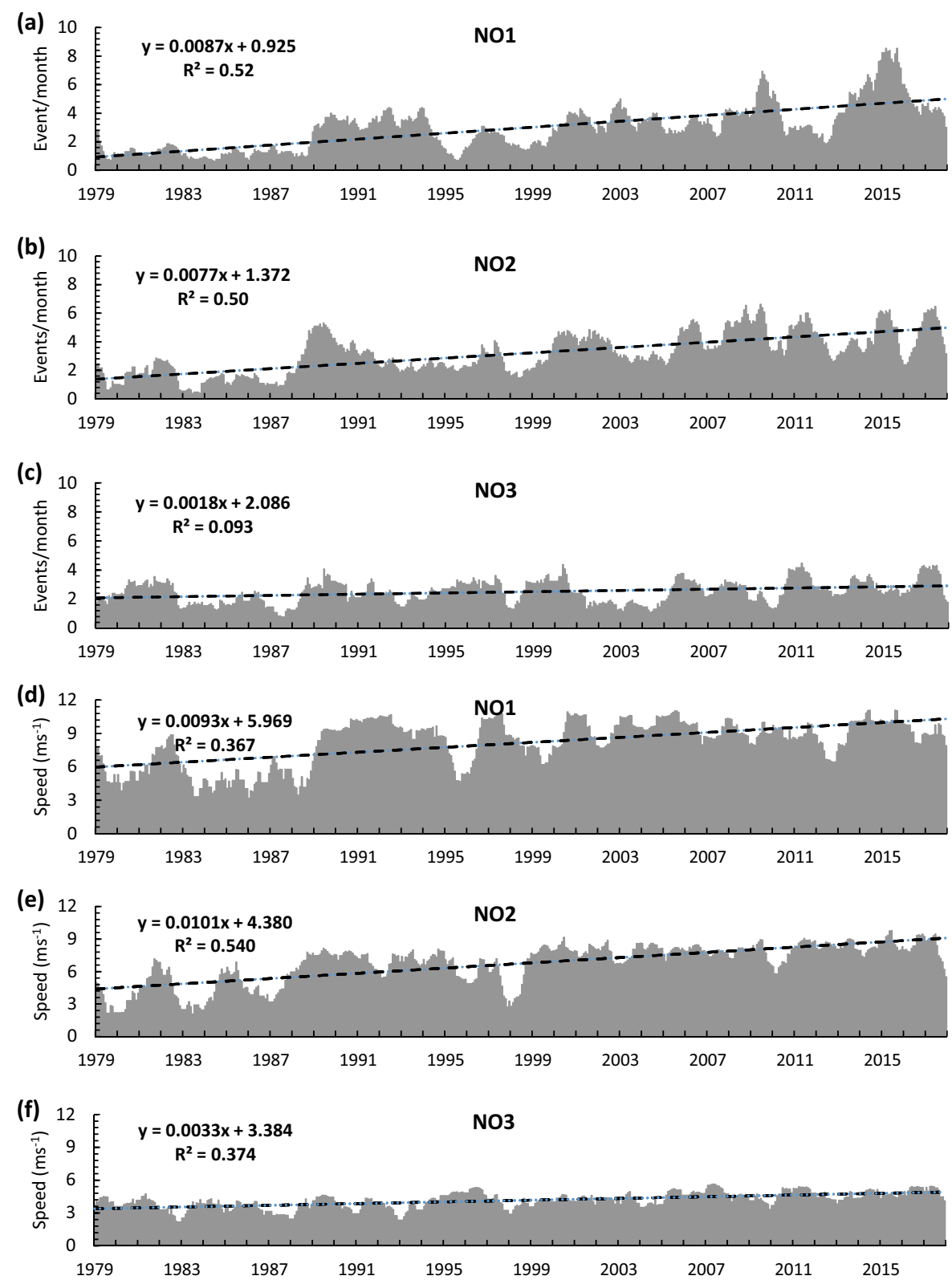

Fig. 6 Monthly time series of frequency (a-c; events per month) and wind speed $\left(\mathbf{d}-\mathbf{f} ; \mathrm{m} \mathrm{s}^{-1}\right)$ during SALLJ northern branch occurrences. Dashed lines show linear trends; equations of linear regressions and explained variances are shown in each panel. Time series were smoothed with 12-month moving averages. Trends are statistically significant (5\% level) based on Mann-Kendall test. Locations: northern Peru (NO3: 3.63S, 75.62W, $173 \mathrm{~m}$ ), Colombia (NO2: 2.93N, 72.37W, $199 \mathrm{~m}$ ), and Venezuela (NO1: 8.18N, 67.45W, $54 \mathrm{~m}$ )

significant increases in recent decades in the northwesterly moisture flux especially in austral spring, summer, and fall, which have possibly enhanced precipitation and extremes over southeastern South America. Additionally, the SALLJ in the central Andes shows decreasing frequency during MAM. This study shows substantial increases in the activity of the SALL northern branch in the last 39 years (Fig. 6). The increase in activity is observed in frequency and intensity of the low-level jet in the northern Andes. These changes in the SALLJ northern branch are part of regional trends in low-level wind shear (Supplementary Fig. S6). In this context, several studies ${ }^{28,29}$ have discussed the cooling trend in the eastern Pacific in recent decades. Figure 5 and Supplementary Fig. S4 show the large-scale circulation patterns that favor the formation of the SALL northern branch. These patterns are associated with negative SST anomalies in the tropical eastern Pacific, and positive anomalies in the North and South Pacific, which have close resemblances with the negative phase of the Interdecadal Pacific Oscillation (IPO). ${ }^{30}$ It is speculated that the large-scale circulation patterns associated with the SALL northern branch projects strongly on the decadal changes in the tropical eastern Pacific and, therefore, could explain the increase in the activity of the low-level jet in the northern Andes.

This study proposes that a thorough understanding of the SALLJ should be studied considering the variability of the lowlevel jet along the entire eastern Andes. In general, global climate models have difficulty in simulating the low-level flow on the eastern Andes, ${ }^{31}$ and, consequently, realistically representing water vapor transport in South America. To increase the confidence in climate projections, global climate models need to be able to represent the variability of the SALLJ as shown in this study based on ERA-I reanalysis. 


\section{METHODS}

Changes in the SALLJ were analyzed with European Centre for MediumRange Weather Forecast Interim Reanalysis (ERA-l), ${ }^{32}$ which are available four times daily at $0.7^{\circ}$ lat/lon horizontal grids. The zonal (U) and meridional (V) components of the wind at 950, 900, 850, 700, 650 and $600 \mathrm{hPa}$, and sea surface temperature (SST) were used to identify and characterize the variability of the SALLJ. Daily gridded $\left(0.5^{\circ}\right.$ lat/lon) precipitation from the National Oceanic and Atmospheric Administration (NOAA) Climate Prediction Center (CPC) unified gauge (CPC-Unified) $)^{33,34}$ was used to characterize the variability of precipitation in South America associated with the SALLJ. The period of analysis for both data sets was from 1 January to 31 December 1979-2017. Daily outgoing longwave radiation (OLR) from NOAA polar orbiting satellites ${ }^{35}$ from 1 January to 31 December 1979-2016 (2.5 lat/lon) was used as a proxy for tropical convective activity. The CPC classification of ENSO events based on the Nino3.4 index was used for the 1 January-31 December 1979-2017 period. Monthly PDO anomalies were obtained from the National Climatic Data Center (NCDC).

A caveat is made about reanalysis products in South America. The spatial density of upper air and precipitation stations in South America is sparse in some locations, increasing the uncertainty of the reanalyses. It should be noted, however, that Montini et al. ${ }^{7}$ carried out a comprehensive comparison of five different reanalyses and radiosondes in the central Andes and showed that the ERA-I well represents the intensity and elevation of the SALLJ (see their Fig. 4).

Occurrences of the SALL in the northern Andes were determined by considering locations in Venezuela (NO1: 8.18N, 67.45W, $54 \mathrm{~m}$ ), Colombia (NO2: 2.93N, 72.37W, $199 \mathrm{~m}$ ) and northern Peru (NO3: 3.63S, $75.62 \mathrm{~W}$, $173 \mathrm{~m})$; similarly, SALLJ events in the central Andes were defined by locations in southern Peru (CE1: 12.42S, 70.133W, $294 \mathrm{~m}$ ), Bolivia (CE2: 17.81S, 63.16W, $400 \mathrm{~m}$ ), and Paraguay (CE3: 22.04S, 60.62W, $43 \mathrm{~m}$ ). These sites were selected to geographically separate the northern and central Andes. Additionally, the sites coincide with locations of positive and negative seasonal trends in wind shear between 850 and $700 \mathrm{hPa}$ discussed next (Supplementary Fig. S6).

To identify SALLJ occurrences, nighttime time series of U850, V850, U700 and V700 were computed by averaging the 00UTC and 06 UTC (i.e., 8:00 p. $\mathrm{m}$. and 02:00 a.m. Bolivia local time) data at each of the six locations separately. To analyze the seasonal cycle in the SALL, long-term trends were removed from these nighttime time series; in contrast, to analyze changes in the SALLJ, long-term trends were retained. Wind speeds at 850 and $700 \mathrm{hPa}$ were computed and wind shear was calculated as the difference in wind speeds between these two levels. Next, monthly frequency distributions of wind speeds and shear were calculated at each location (see also Montini et al. ${ }^{7}$ ). A SALLJ event was deemed to have occurred when the following three conditions were met simultaneously: (1) wind speed at $850 \mathrm{hPa} \geq 75$ th monthly percentile, (2) SHEAR $850-700 \geq$ 75th monthly percentile, and (3) V850 $<0$. The following terminology is used here. We refer to northern branch SALL, when the low-level jet occurs in at least one of the three locations in the northern region and no low-level jet happens in the central domain. Likewise, SALLJ central branch occurs when the low-level jet happens in on the three locations in the central Andes and no low-level jet is present in the northern domain. A simultaneous SALLJ refers to low-level jet occurrence in both northern and central regions. Lead-lag relationships between northern and central SALLJ branches were not analyzed. The overall frequencies of SALLJ occurrences are: 9.7\% (NO1), 10.5\% (NO2), 8.2\% (NO3), 9.1\% (CE1), 10.8\% (CE2), and $14.1 \%$ (CE3) during 1 January-31 December 1979-2017. The seasonal frequency distributions of northern, central, and simultaneous SALLJs are shown in Fig. 3. The vertical profiles of the northern and central SALLJ were analyzed by averaging wind speeds at 950, 900, 850, 700, 650, and $600 \mathrm{hPa}$ and each season separately (Fig. 1).

Seasonal mean winds $(850 \mathrm{hPa})$ were calculated by averaging winds during SALL days in the northern (Fig. 2) and central (Fig. S2) Andes. To analyze the influence of the SALL in the northern and central branches on precipitation, the daily climatology was first obtained by averaging precipitation on each calendar day during 1979-2017, and fitting annual and semi-annual harmonics. Precipitation anomalies were computed by removing the daily precipitation climatology. Figure 4 shows mean precipitation anomalies for days with SALL northern branch events; Fig. S3 shows mean precipitation anomalies for days with SALLJ central branch. Statistical significance at $5 \%$ level was assessed with a $z$-score test. ${ }^{36}$

To characterize large-scale atmospheric circulation patterns, two calculations were performed. Figure 5 shows differences in OLR, SST, and wind anomalies $(200 ; 850 \mathrm{hPa})$ between northern branch SALLJ days minus no low-level jet days in the northern region. The sample sizes of northern branch events were 2089 days (1 December-31 January, 1979-2017) and 2020 (1 December-31 January, 1979-2016); sample sizes of low-level jet free days in the northern domain were 12,156 days (1 December-31 January, 1979-2017) and 11,860 days (1 December-31 January, 1979-2016). Similarly, Fig. S4 shows differences in OLR, SST and wind anomalies $(200 ; 850 \mathrm{hPa})$ between northern branch minus central branch days. Sample sizes were: (1) northern branch 2089 days (1 December-31 January, 1979-2017) and 2020 days (1 December-31 January, 1979-2016), (2) central branch 2476 days (1 December-31 January, 1979-2017) and 2404 days (1 December-31 January, 1979-2016). The statistical significance (5\% level) of the anomalies was assessed with a standard test of differences in means. ${ }^{36}$ To identify potential relationships with the phases of ENSO and PDO, Fig. S5 shows a scatterplot of northern branch SALL events as a function of ENSO and PDO.

The characterization of changes in the northern branch SALLJ was done in two ways. For each location in the northern Andes, a time series was created by counting the number of low-level jet days in each calendar month resulting in a metric of monthly frequency of occurrence. Likewise, for each location, another time series was created by averaging the wind speed $(850 \mathrm{hPa})$ during low-level jet days in each calendar month; this time series is a monthly metric of SALLJ intensity. Before calculation of linear trends, a 1-year running mean was used to smooth the two metrics; this is necessary because the frequency of northern branch SALLJ is zero during some months, which results in abrupt discontinuities in both metrics. Figure 6 shows the monthly metrics of frequency and intensity as well as linear trends in each location in the northern Andes. Mann-Kendal tests ${ }^{36}$ indicate that all trends in the northern branch SALLJ are statistically significant at $5 \%$ level.

Changes in the mean state were investigated with respect to occurrences of northern branch SALL. First, the annual cycle was removed from the time series of $\mathrm{U}(850,700 \mathrm{hPa})$ and $\mathrm{V}(850,700 \mathrm{hPa})$ by subtracting the daily climatology determined by the annual mean and first two harmonics. Trends were retained in these time series. Wind shear anomaly was computed as the difference in wind speed anomalies between 850 and $700 \mathrm{hPa}$. Next, monthly wind shear anomalies were computed by averaging on northern branch SALLJ days. Monthly time series were additionally smoothed with 3-year moving average windows to reduce the effect of interannual variations and focus on long-term trends. Figure S6 shows seasonal trends in wind shear estimated with the Sen's slope estimator and statistical significance $(5 \%$ level) determined with Mann-Kendal test. ${ }^{36}$ Note that the selection of reference gridpoints in the northern and central Andes are embedded in regions of positive and negative trends in wind shear $(850-700 \mathrm{hPa})$. The selection of gridpoints was not based on the most positive/negative trends in wind shear, but rather the proximity to the eastern slopes of the Andes, where the SALLJ is known to occur.

\section{DATA AVAILABILITY}

The research presented here was derived from data sets that are all publicly available.

\section{CODE AVAILABILITY}

Interactive Data Language (IDL) computer code was used for data processing and analyses. Computer codes are available from the author upon reasonable requests.

\section{ACKNOWLEDGEMENTS}

The author would like to thank Leila M. V. Carvalho for helpful discussions and comments on the research topic. The ERA Interim reanalysis was downloaded from the Research Data Archive at the National Center for Atmospheric Research, Computational and Information Systems Laboratory, Boulder, CO. [Available online at https://rda.ucar.edu/datasets/ds626.0]. The authors also thank the European Centre for Medium-Range Weather Forecasts (ECMWF) for making the reanalysis available for this research. The gridded precipitation was provided by the Climate Prediction Center from the National Centers for Environmental Prediction (NCEP). Outgoing longwave radiation data from polar orbiting satellites were provided by the International Research Institute (IRI) for Climate and Society, Columbia University.

\section{AUTHOR CONTRIBUTIONS}

C.J. defined the objectives of this study and was responsible for downloading the data, performing the analyses, and writing the manuscript. 


\section{ADDITIONAL INFORMATION}

Supplementary Information accompanies the paper on the npj Climate and Atmospheric Science website (https://doi.org/10.1038/s41612-019-0077-5).

Competing interests: The author declares no competing interests.

Publisher's note: Springer Nature remains neutral with regard to jurisdictional claims in published maps and institutional affiliations.

\section{REFERENCES}

1. Virji, H. A Preliminary study of summertime tropospheric circulation patterns over South America estimated from cloud winds. Mon. Weather Rev. https://doi.org/ 10.1175/1520-0493(1981)109<0599:APSOST>2.0.CO;2 (1981).

2. Vera, C., Silvestri, G., Liebmann, B. \& Gonzalez, P. Climate change scenarios for seasonal precipitation in South America from IPCC-AR4 models. Geophys. Res. Lett. 33, https://doi.org/10.1029/2006GL025759 (2006).

3. Paegle, J. et al. Modeling studies related to SALLJEX. Exch. CLIVAR Newsl. 9, 20-22 (2004).

4. Marengo, J. A., Soares, W. R., Saulo, C. \& Nicolini, M. Climatology of the low-level jet east of the Andes as derived from the NCEP-NCAR reanalyses: characteristics and temporal variability. J. Clim. 17, 2261-2280 (2004).

5. Berri, G. J. \& Inzunza, J. B. The effect of the low-level jet on the poleward water vapour transport in the central region of South America. Atmos. Environ. Part A. Gen. Topics 27, 335-341 (1993).

6. Marengo, J. A. et al. Recent developments on the South American monsoon system. Int. J. Climatol. 32, 1-21 (2012).

7. Montini, T. L., Jones, C. \& Carvalho, L. M. V. The South American low-level jet: a new climatology, variability, and changes. J. Geophys. Res. Atmos. https://doi.org/ 10.1029/2018JD029634 (2019).

8. Vera, C. et al. The South American low-level jet experiment. Bull. Am. Meteorol. Soc. 87, 63-77 (2006).

9. Carvalho, L. M. V. \& Jones, C. Monsoons and Climate Change: Observations and Modeling. p 253 (Springer, New York, Dordrecht, London, 2016).

10. Liebmann, B. \& Mechoso, C. R. The South American Monsoon System. In The Global Monsoon System: Research and Forecast, 2nd edn (eds. Chang, C. P. et al.). 550 (World Scientific Publishing, Singapore, 2010).

11. Vera, C. et al. Toward a unified view of the American Monsoon Systems. J. Clim. 19, 4977-5000 (2006).

12. Nascimento, M. G., Herdies, D. L. \& de Souza, D. O. The South American water balance: the influence of low-level jets. J. Clim. 29, 1429-1449 (2016).

13. Jones, C. \& Carvalho, L. M. V. The influence of the Atlantic multidecadal oscillation on the eastern Andes low-level jet and precipitation in South America. npj Clim. Atmos. Sci. 1, 40 (2018).

14. Marengo, J. A., Douglas, M. W. \& Dias, P. L. S. The South American low-level jet east of the Andes during the 1999 LBA-TRMM and LBA-WET AMC campaign. J. Geophys. Res. 107, 8079, (2002).

15. Liebmann, B., Kiladis, G. N., Vera, C. S., Saulo, A. C. \& Carvalho, L. M. V. Subseasonal variations of rainfall in South America in the vicinity of the low-level jet east of the Andes and comparison to those in the South Atlantic convergence zone. J. Clim. 17, 3829-3842 (2004).

16. Wang, H. \& Fu, R. Influence of cross-Andes flow on the South American low-level jet. J. Clim. 17, 1247-1262 (2004).

17. Campetella, C. M. \& Vera, C. S. The influence of the Andes mountains on the South American low-level. Geophys. Res. Lett. 29, 7-1-7-4 (2002).

18. Sun, X. M. \& Barros, A. P. Isolating the role of surface evapotranspiration on moist convection along the eastern flanks of the Tropical Andes using a quasi-Idealized approach. J. Atmos. Sci. 72, 243-261 (2015).
19. Berbery, E. H. \& Barros, V. R. The hydrologic cycle of the La Plata basin in South America. J. Hydrometeorol. 3, 630-645 (2002).

20. Romatschke, U. \& Houze, R. A. Characteristics of precipitating convective systems accounting for the summer rainfall of tropical and subtropical South America. J. Hydrometeorol. 14, 25-46 (2013).

21. Romatschke, U. \& Houze, R. A. Extreme summer convection in South America. J. Clim. 23, 3761-3791 (2010).

22. Rasmussen, K. L. \& Houze, R. A. Convective Initiation near the Andes in Subtropical South America. Mon. Weather Rev. 144, 2351-2374 (2016).

23. Salio, P. et al. Mesoscale convective systems over southeastern South America and their relationship with the South American low-level jet. Mon. Weather Rev. 135, 1290-1309 (2007).

24. Exchanges. South American low level jet experiment SALLJEX. Clim. Var. Predict. (CLIVAR) Newsl. 9, 32 (2004).

25. Torrealba, E. R. \& Amador, J. A. La corriente en chorro de bajo nivel sobre los Llanos Venezolanos de Sur América. Rev. Climatol. 10, 1-20 (2010).

26. Yepes, J. et al. CHOCO-JEX: a research experiment focused on the CHOCO lowlevel jet over the far Eastern Pacific and Western Colombia. Bull. Am. Meteorol. Soc. BAMS-D-18-0045.1 (2019). https://doi.org/10.1175/BAMS-D-18-0045.1

27. Wang, C. Variability of the Caribbean low-level jet and its relations to climate. Clim. Dyn. 29, 411-422 (2007).

28. Li, X., Xie, S.-P., Gille, S. T. \& Yoo, C. Atlantic-induced pan-tropical climate change over the past three decades. Nat. Clim. Chang. 6, 275-279 (2016).

29. Takahashi, C. \& Watanabe, M. Pacific trade winds accelerated by aerosol forcing over the past two decades. Nat. Clim. Chang. 6, 768-772 (2016).

30. Henley, B. J. et al. A Tripole Index for the Interdecadal Pacific Oscillation. Clim. Dyn. 45, 3077-3090 (2015).

31. Barros, V. R. \& Doyle, M. E. Low-level circulation and precipitation simulated by CMIP5 GCMS over southeastern South America. Int. J. Climatol. 38, 5476-5490 (2018).

32. Dee, D. P. et al. The ERA-Interim reanalysis: configuration and performance of the data assimilation system. Q. J. R. Meteorol. Soc. 137, 553-597, (2011).

33. Higgins, R. W., Shi, W., Yarosh, E. \& Joyce, R. Improved United States Precipitation Quality Control System and Analysis. NCEP/Climate Prediction Center ATLAS No. 7, National Oceanic and Atmospheric Administration, 40 pp. (2000).

34. Chen, M. Y. et al. Assessing objective techniques for gauge-based analyses of global daily precipitation. J. Geophys. Res. 113, 1-13 (2008).

35. Liebmann, B. Description of a complete (interpolated) outgoing longwave radiation dataset. Bull. Am. Meteorol. Soc. 77, 1275-1277 (1996).

36. Wilks, D. S. Statistical Methods in the Atmospheric Sciences, 2nd edn, Vol. 91 (Academic Press, Inc. San Diego, CA, USA, 2011).

(i) Open Access This article is licensed under a Creative Commons cc) Attribution 4.0 International License, which permits use, sharing, adaptation, distribution and reproduction in any medium or format, as long as you give appropriate credit to the original author(s) and the source, provide a link to the Creative Commons license, and indicate if changes were made. The images or other third party material in this article are included in the article's Creative Commons license, unless indicated otherwise in a credit line to the material. If material is not included in the article's Creative Commons license and your intended use is not permitted by statutory regulation or exceeds the permitted use, you will need to obtain permission directly from the copyright holder. To view a copy of this license, visit http://creativecommons. org/licenses/by/4.0/.

(c) The Author(s) 2019 